\title{
Flower-visiting guild associated with the Caatinga flora: trophic interaction networks formed by social bees and social wasps with plants*
}

\author{
Gilberto M. de Mendonça Santos ${ }^{1}$, Cândida M. Lima AguiaR ${ }^{1}$, Marco A.R. Mello ${ }^{2}$ \\ ${ }^{1}$ Laboratório de Entomologia, Departamento de Ciências Biológicas, Universidade Estadual de Feira \\ de Santana, Feira de Santana, Bahia, Brasil \\ ${ }^{2}$ Departamento de Botânica, Universidade Federal de São Carlos, São Carlos, SP, Brasil
}

Received 1 May 2009 - Revised 13 October 2009 - Accepted 15 October 2009

\begin{abstract}
We conducted a comparative analysis of bee-plant and wasp-plant interaction networks, aiming at the identification of similarities and differences between networks of flower-visiting groups with direct or indirect mutualism with plants. We measured for each network: number of social bees and social wasps, number of plants visited (P), degree of nestedness, number of observed (I) and possible interactions, connectance (C), and interaction density (D). The network formed by pooling together social bees and social wasps exhibited 25 species ( 12 bees and 13 wasps) and 49 visited plants, with a connectance of $15.34 \%$. The wasp-plant network had higher connectance $(C=21.24)$ than the bee-plant network $(C=15.79)$. Both the social wasp-plant and the social bee-plant network were significantly nested, they presented structure more nested than all randomly generated matrices $(n=1000)$. Both interaction networks have similar topologies and are nested, asymmetrical and modular structures.
\end{abstract}

flower-visiting guild / food network / trophic interactions / semi-arid region

\section{INTRODUCTION}

Flower-visiting guilds can be analyzed by focusing on different aspects. The interaction between social bees and flowering plants has been widely studied, most often by analysing the structure of the mutualistic network (e.g. Olesen and Jordano, 2002; Memmott et al., 2004; Biesmeijer et al., 2005), food niche breadth and niche overlap (Wilms and Wieschers, 1997; Aguiar, 2003), and by studying the role of social bees as pollinators (Heard, 1999). On the other hand, fewer studies focusing on the interactions between social wasps and floral resources have been conducted (Heithaus, 1979; Hermes and Köhler, 2006; Aguiar and Santos, 2007).

Corresponding author: C.M.L. Aguiar, candida.aguiar@gmail.com

* Manuscript editor: Jacqueline Pierre
Social wasps interact with flora in a unique way: although they are frequent floral visitors for the collection of resources needed for survival, they are seldom pollinators. Some species of social wasps have been observed eating pollen (Hunt et al., 1991; Jones and Jones, 2001). However, differently from bees, the morphology of social wasp is not welladapted for pollen collection and transportation. Social wasps visit flowers to collect nectar, fibres for nest building or to hunt small insects associated with the flowers (Gess and Gess, 1993).

Bees and social wasps are among the main components of floral resource-collecting guilds in the Neotropical region. The interactions between bees and plants results usually in a direct mutualism where bees pollinate flowers while obtaining food from them (however, not all bees are effective pollinators 
of the plants they visit). Social wasps can act both as flower visitors and as generalist predators (Resende et al., 2001; Beggs, 2001). The interaction between social wasps and plants may be considered as an indirect mutualism because the plants provide resources and the wasps may provide protection against herbivores for the plants visited, benefiting them indirectly.

Network theory has helped much to understand the community structure of mutualisms by revealing some invariant properties of those systems (Jordano et al., 2003), and also by understanding these properties in the context of many kinds of complex networks (Bascompte and Jordano, 2007). Therefore, we compared a social bee-plant with a social wasp-plant network occurring in a "Caatinga" vegetation to identify similarities and differences in the networks formed by two flower-visiting taxa, presenting direct mutualism (food $\times$ pollination) or indirect mutualism (food $\times$ protection against herbivory). Because both kinds of network represent mutualisms between free-living organisms, we expected them to exhibit a nested structure, as observed in other similar networks (Bascompte et al., 2003). We also expected similar patterns of linkage density, connectance and degree distribution, which are also invariant properties of mutualisms (Jordano et al., 2003). However, considering that bees and wasps come from different evolutionary lineages of hymenopterans, and that they have different interests while visiting flowers, we expected some differences between their networks, as phylogeny seems to play a role in network structure (Jordano, 1987; Bezerra et al., 2009). We expected the bee-plant network to have a higher degree of modularity compared with the wasp-plant network, considering that bees depend on floral resources (nectar/pollen) much more than wasps, and thus the degree of intimacy of interactions among bees and plants is higher than between wasps and plants.

\section{MATERIAL AND METHODS}

We constructed networks using our previously published data on interactions between bees and plants (Aguiar, 2003), and wasps and plants (Santos et al., 2006). Samples of social bees and wasps visiting flowers were collected in the municipality of Itatim ( $\left.12^{\circ} 42^{\prime} \mathrm{S} ; 39^{\circ} 46^{\prime} \mathrm{W}\right)$, State of Bahia, Brazil, in an area covered by a mosaic of "Caatinga", a typical semi-arid vegetation of Northeastern Brazil. The study area included both shrubby and semideciduous arboreal "caatinga" vegetation. A detailed description of the vegetation physiognomy and floristic composition can be found in França et al. (1997). Samples were collected from November 1996 to November 1997, on a monthly basis, along a $3 \mathrm{~km}$ long and $20 \mathrm{~m}$ wide transect. Two collectors carefully and simultaneously inspected each flowering plant for 5 minutes and flower-visiting bees and wasps were captured using entomological nets.

Each bipartite network (bee-plant and waspplant) was described by an adjacency matrix $R$, in which rows were bee or wasp species and columns were plant species visited. The element rij $=1$ meant that bee/wasp species i was observed visiting flowers of plant species $\mathrm{j}$, and rij $=0$ that bee/wasp species i did not visit plant species $\mathrm{j}$. We followed an approach used previously in other network studies including bee-plant networks (e.g Vázquez and Aizen, 2004; Aizen et al., 2008), which consider all interacting species as part of the mutualistic network (Jordano et al., 2003). Graphs of two-mode networks were drawn with the "bipartite" package running in $\mathrm{R}$ (Dormann et al., 2009).

To compare bee-plant and wasp-plant networks, we measured for each network: number of social bees and social wasps, number of plants visited (P), degree of nestedness, number of observed (I) and possible interactions, connectance $(\mathrm{C})$, and interaction density (D) (Bascompte et al., 2003; Bascompte and Jordano, 2006; Guimarães et al., 2006a). Each flower-visiting species recorded on a plant species represented an observed interaction (or link) (I). The interaction density (D) is the mean number of interactions per plant species, and we calculated D separately for each network (bee-plant and wasp-plant). We used the number of observed interactions (I) and the Connectance (C) as measures of generalization. Connectance is given by $\mathrm{C}=100 \mathrm{I} / \mathrm{NS}$, where NS (Network size) corresponds to the number of interactions theoretically possible in a network, and it is given by NS = VP, where $\mathrm{V}$ is the number of flower-visiting species and $\mathrm{P}$ is the number of visited plant species. Connectance is thus the percentage of all possible interactions actually observed within a network (see 
Bascompte et al., 2003; Biesmeijer et al., 2005; Bascompte and Jordano, 2006; Guimarães et al., 2006b).

We measured the degree of nestedness of each network using distinct metrics: NODF (nestedness metric based on overlap and decreasing fill) (Almeida-Neto et al., 2008) and $\mathrm{N}$ (based on matrix temperature, $\mathrm{T}$, where $\mathrm{N}=(100-\mathrm{T}) / \mathrm{T})($ Atmar and Paterson, 1993); both indexes vary from 0 to 1 , and values near 1 indicate a highly nested structure. According to Guimarães et al. (2006a), "nestedness is a specific type of asymmetric interaction characterized by (i) species with many interactions form a core of interacting species, (ii) species with few interactions commonly interacts only with species with many interactions and (iii) the absence of interactions between species with few interactions".

We estimated the significance of both metrics (NODF and N) with Monte Carlo procedures (1 000 randomizations) in the software Aninhado software (Guimarães and Guimarães, 2006). We used the null model 2 from Bascompte et al. (2003), which assumes that the probability that a flower-visiting species interacts with a plant depends on the observed number of interactions of both species.

To assess the network properties of particular species, we used the importance index (Ij) (Murray, 2000), which varies from 0 to 1 , to evaluate the importance of each plant species for each flowervisiting group (bees or wasps). In the equation $\mathrm{Ij}=$ $\Sigma[(\mathrm{Cij} / \mathrm{Ti}) / \mathrm{S}], \mathrm{Ti}$ is the total number of plant species visited by each visiting species, $\mathrm{S}$ the total number of visiting species, and Cij corresponded to the binary data $(0 / 1)$. This index tends to 1 , when a plant species has many interactions in the community or has a large number of exclusive interactions (Murray, 2000).

Modularity in both kinds of network was assessed with the $\mathrm{M}$ index (Guimerà and Amaral, 2005), which considers the number of subgroups on the network and linkage density within each subgroup and among subgroups, and is obtained through a simulated annealing procedure. The significance of the $M$ index was estimated with a Monte Carlo procedure (1000 randomizations). One-mode graphs resulting from the modularity analysis were drawn in Pajek 1.24 (Batagelj and Mrvar, 2003).

\section{RESULTS}

Thirteen species of social wasps visited flowers of 42 plant species, and 12 social bees species visited 38 plant species. Both social wasp-plant and social bee-plant networks exhibited a nested structure (Fig. 1). The degree of nestedness was intermediate in both kinds of network as measured with the NODF metric (wasp-plant $=0.43, P=(P<0.001)$; and bee-plant $=0.49, P=(P<0.001)$. However, nestedness was very high considering the $\mathrm{N}$ metric in both cases [wasp-plant $=0.84$, $P=(P<0.001)$; and bee-plant $=0.95$; $P=(P<0.001)]$. Our data generated matrices (bee-plant and wasp-plant) were more nested (calculated by NODF and N) than randomly generated matrices $(n=1000$ to bee-plant and $\mathrm{n}=1000$ to wasp-plant).

The social wasp-plant network performed 116 from the 546 possible interactions and had connectance of $\mathrm{C}=21.24$. The social beeplant network had 72 of the 456 possible interactions, and connectance of $\mathrm{C}=15.79$.

Seven flower-visiting species formed a core of the wasp-plant network (Polybia ignobilis, $P$. sericea, $P$. paulista, $P$. occidentalis, Polistes canadensis, Brachygastra lecheguana, and Protonectarina sylveirae), accounting for $87.93 \%$ of the interactions in the social wasp-plant network. The number of interactions of the 7 most generalistic (sensu Biesmeijer et al., 2005) wasp species was seven times larger than that for the six species with fewer interactions. Six species were particularly important in structuring the bee-plant network (Apis mellifera, Trigona spinipes, Frieseomelitta silvestrii, Plebeia sp., Trigonisca intermedia, and Melipona asilvai), with $90.28 \%$ of the interactions in the social bee-plant network. The number of interactions of the 6 most generalistic species (sensu Biesmeijer et al., 2005) was 6 times larger than that for the 6 species with fewer interactions. The topology of the bee-plant network was strongly influenced by $A$. mellifera, an exotic and highly generalistic species that interacts with 33 out of the 38 plant species $(89.47 \%)$.

The whole network formed by pooling together social bees and social wasps exhibited 25 flower-visiting species and 49 plants (Fig. 1), with a connectance (C) of $15.34 \%$. One-hundred eighty-eight interactions were observed, out of the 1225 possible. Nine flower-visiting species accounted for $78.19 \%$ 


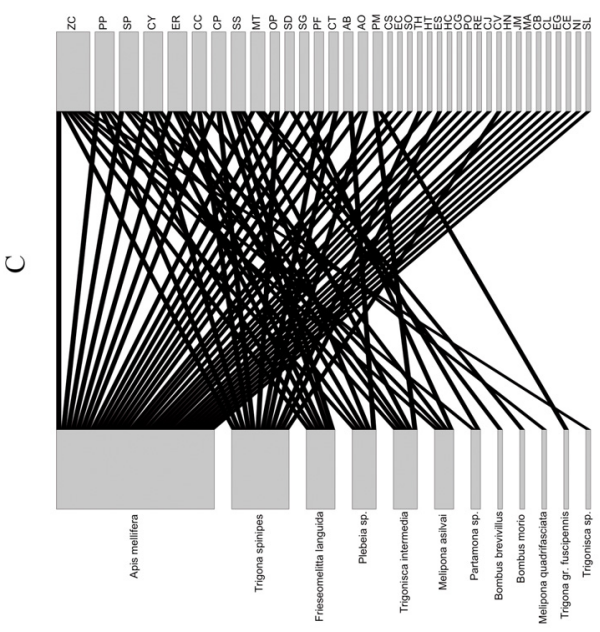

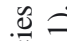

क्ष

象

包

㐫哇

롱

过

.

ర্口0

U.

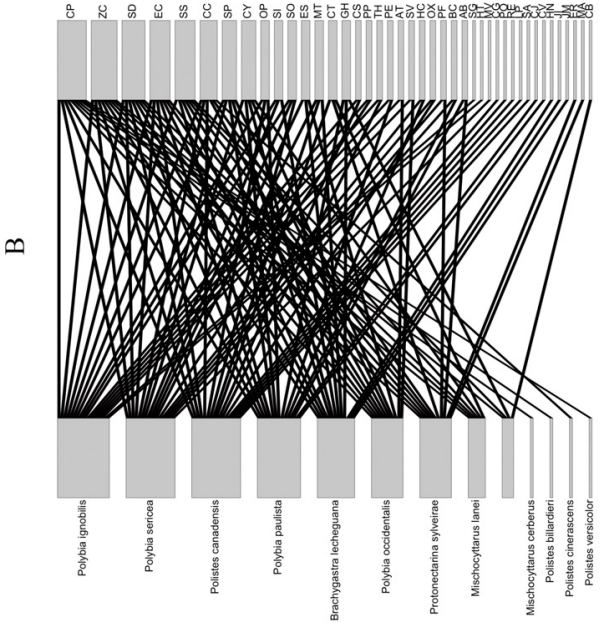

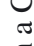

.

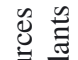

氕

के

준 $\frac{9}{7}$

은

离昜

范

帘

릉

के

\&

즁

पै

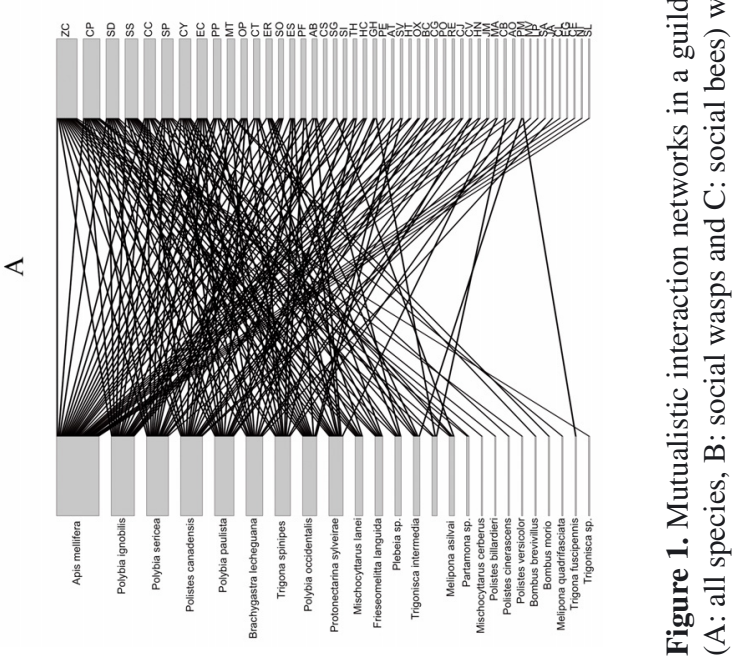



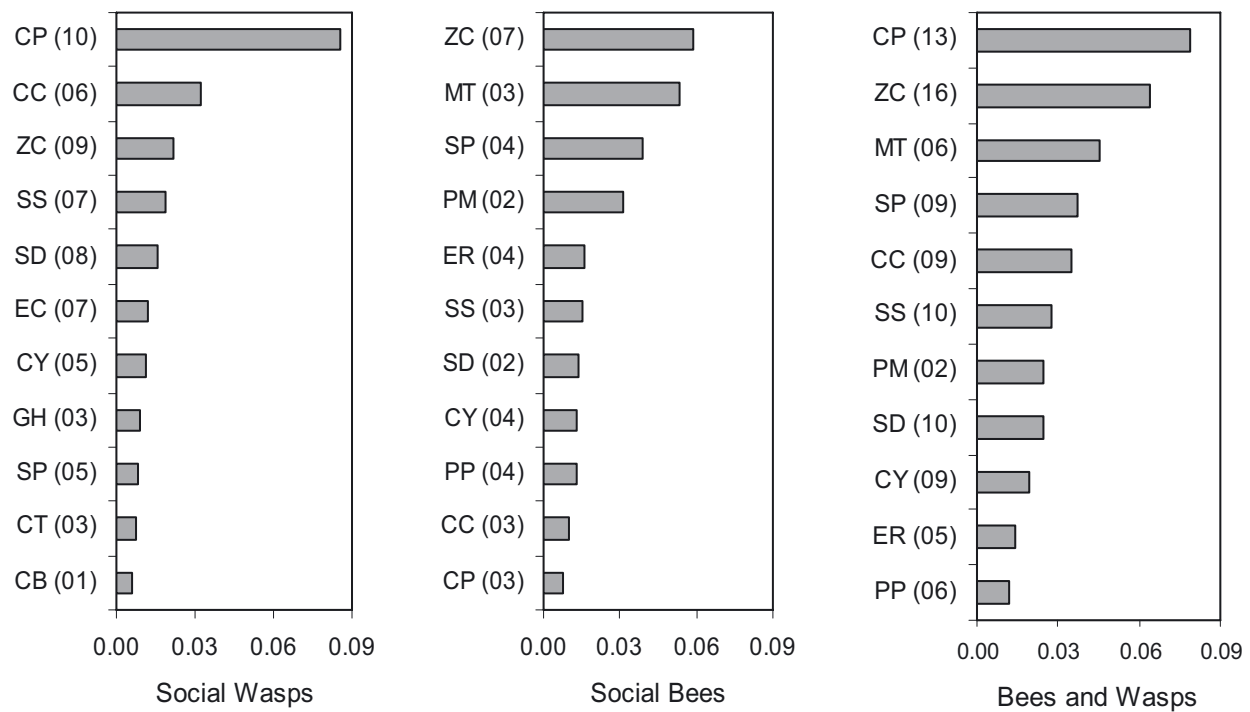

Figure 2. Importance index (Ij) for the main plant species suppliers of floral resources for social wasps ( $\mathrm{Ij}=0.0013$ to 0.0854$)$, social bees ( $\mathrm{Ij}=0.0008$ to 0.0587$)$, and for both groups ( $\mathrm{Ij}=0.0006$ to 0.0790$)$. In parenthesis, the number of interactions for each plant (see abbreviation of the plants in Appendix 1).

of all connections: Apis mellifera (33 interactions), Polybia ignobilis (18), P. sericea (17), Polistes canadensis (17), P. paulista (15), Brachygastra lecheguana (13), Trigona spinipes (12), P. occidentalis (11), and Protonectarina sylveirae (11).

A relatively high proportion of plant species was visited both by social bees and social wasps $(63.26 \%, \mathrm{~N}=31)$, whereas eighteen plant species $(36.73 \%)$ were visited by only one group: 11 species were visited only by social wasps and 7 only by social bees. Five of the seven plant species visited exclusively by bees were visited only by $A$. mellifera, an invasive alien species.

As bees and wasps establish different kinds of interactions with the flora, a particular plant species may exhibit different importance values in each network (Fig. 2). Caesalpinia pyramidalis showed the highest importance index for social wasps (10 interactions; $\mathrm{Ij}=$ 0.0790), whereas Ziziphus cotinifolia showed the highest importance index for social bees ( 7 interactions; $\mathrm{Ij}=0.0587$ ) (Fig. 2). This plant had the highest number of observed interactions $(I=16)$ with the flower-visitors.
The mean interaction density (D) between social wasps and the plant species visited only by this group was 1.90 interactions/plant, while the mean interaction density between social bees and the plant species visited only by this group was 1.14 interaction/plant. The modularity of the whole network (bees and wasps together) was relatively low $(\mathrm{M}=0.07$, $P=0.004$ ) (Fig. 3). There were only two subgroups in the whole network that interacted with slightly different subsets of plants. However there was a high mixture of bees and wasps in each subgroup. The modularity of the network formed only by bees was seven times higher $(\mathrm{M}=0.14, P=0.01)$ than the modularity of the wasp network $(\mathrm{M}=0.02$, $P=0.007)$. In the bee-plant network three subgroups were detected, while in the waspplant network there were only two subgroups.

\section{DISCUSSION}

We observed that the flower-visiting networks formed by wasps and plants and bees and plants are very similar in structure, despite representing different kinds of mutualism (defence and pollination, respectively). 
A

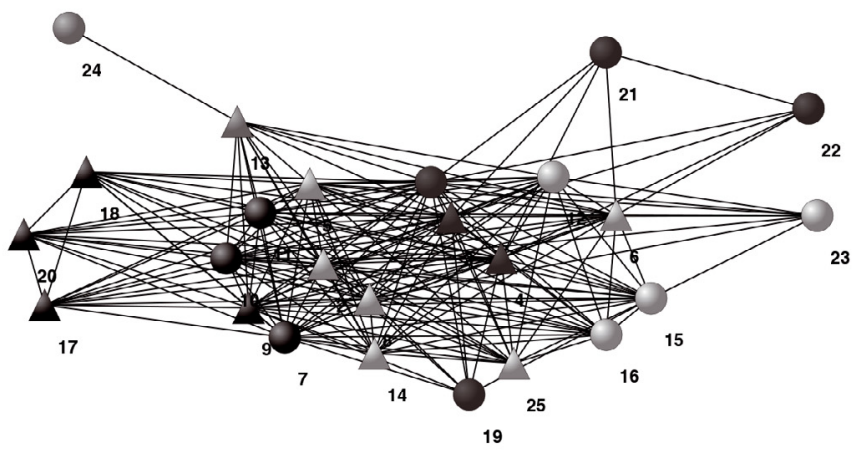

Apis mellifera

Polybia ignobilis

Polybia sericea

4 Polistes c'anadensis

5 Polybia paulista

6 Brachygastra lecheguana

7 Trigona spinipes

8 Polybia occidentalis

Protonectarina sylveira

0 Mischocyttarus lanci

11 Frieseomelitta languida

12 Plebeia sp.

13 Trigonisca intemnedia

14 Protopolybia exígua

15 Melipona asilvai

16 Partamona sp.

17 Mischocyttarus cerberus

18 Polistes billardieri

19 Polistes cinerascens

20 Polistes versicolor

21 Bombus brevivillus

22 Bombus morio

23 Melipona quadrifasciata

24 Trigona fuscipennis

25 Trigonisca sp.

\section{B}

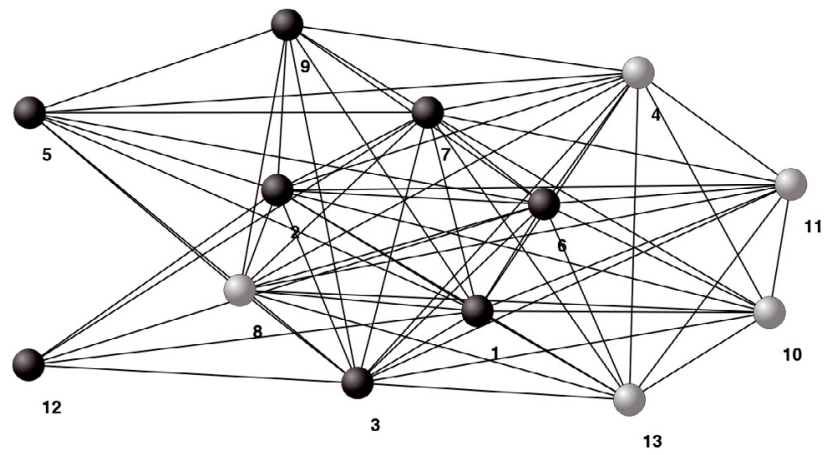

1 Polybia ignobilis

2 Polybia sericea

3 Polistes canadensis

4 Polybia paulista

5 Brachygastra lecheguana

6 Polybia occidentalis

7 Protonectarina sylveirae

8 Mischocyttarus lanei

9 Protopolybia exígua

10 Mischocyttarus cerberus

11 Polistes billardieri

12 Polistes cinerascens

13 Polistes versicolor

$\mathrm{C}$

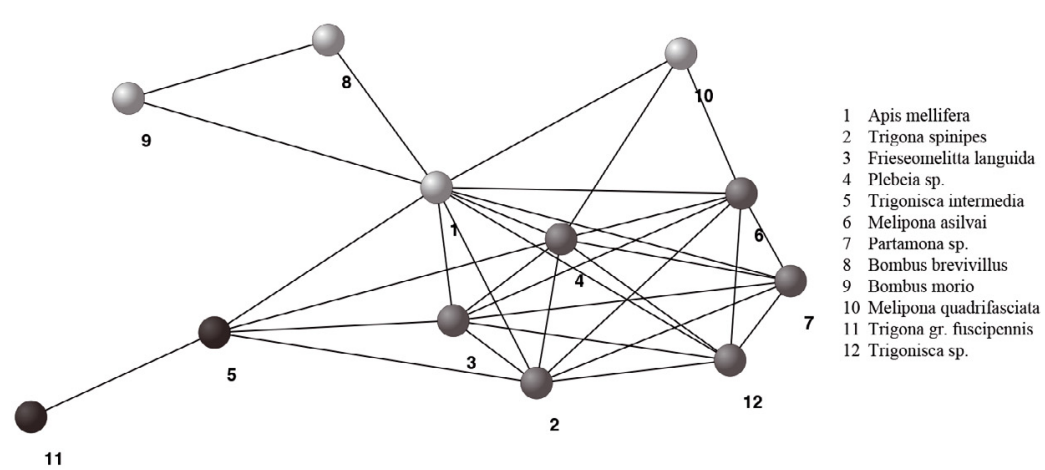

Figure 3. Graphs representing the modular structure (subgroups) of (A) the whole network, (B) the waspplant network and (C) the bee-plant network. All graphs are one-mode projections of their original networks and comprise only animal species (bees, wasps or both). Grey tones represent different modules identified in the analysis. In graph A, wasps are represented as triangles, and bees as ellipses. 
Our findings reinforce the paradigm that facultative mutualisms result in similar network structures (Bascompte et al., 2003).

The structure of both wasp-plant and beeplant networks was more nested than expected under null models. The nested structure of the bee-plant and the wasp-plant networks is consistent with other types of facultative mutualism, including pollination and seed dispersal (Bascompte et al., 2003), clownfish-anemone (Ollerton et al., 2007) and marine cleaning symbiosis (Guimarães et al., 2006b). A nested structure is presumed to increase network stability and biodiversity maintenance and, therefore, is considered as an evolutionary-stable strategy (Bascompte et al., 2006). It seems that nestedness is a common configuration in facultative mutualism, because species have a relatively high freedom of changing partners (Bascompte and Jordano, 2007).

The higher connectance of the social waspsplant network suggests that social wasps were more generalistic than social bees. However, we must be cautious about this preliminary conclusion and conduct further comparative studies with other wasp-plant and bee-plant networks. Additionally, the analysis of modularity in the whole network showed a higher clustering of niches among bees, evidencing indirectly that their higher dependence on the flowers may lead to higher interspecific competition and to niche segregation and subgroup formation. On the other hand, wasps have a weaker relationship with plants, and so niche overlap among wasp species is stronger and modularity is lower.

Only 31 of the 49 plant species visited were used by both groups in this flower-visiting guild. Social bees and social wasps behave similarly during nectar foraging and are, therefore, often cited as generalist and opportunistic. However, our analysis of interaction networks metrics and importance index, showed a clear difference in the relative importance of different plant species as food resource for each of the flower-visiting groups. When looking at the details we noticed that the dependence of wasps and bees on particular plants differed. Our findings support previous data on trophic niches collected for the same taxa, in which relatively low niche overlap levels between social wasps and social bees were observed (Aguiar and Santos, 2007).

According to our data, the exotic species A. mellifera is important both in the bee-plant interaction network and in the overall flowervisiting network. Therefore, further and more detailed studies are needed to measure the levels of invasion of this species in bee communities of Brazilian ecosystems.

In summary, our findings point out that facultative mutualisms produce networks with similar properties. Despite the small differences in topology, in the interaction density, and in the specific aspects of mutualism between bees and plants (direct mutualism - pollination) or wasps and plants (indirect mutualism - defense), both interaction networks have asymmetrical nested topologies with some degree of modularity. A more detailed analysis of the network properties of particular plants and animals suggests that despite those similarities at the network level, future studies should look more cautiously on what is found at the species level. Understanding how different species vary in their importance to the maintenance of network structure and their ecosystem services is crucial for conservation.

Guilde de butineuses associée à la flore de la Caatinga : réseau d'intéractions trophiques formé entre les abeilles sociales, les guêpes sociales et les plantes.

guilde de butineurs / réseau trophique / région semi-aride / relations plante-insecte / Brésil

\section{Zusammenfassung - Eine mit der Caatinga- Flora assoziierte Gilde blütenbesuchender In- sekten: trophische Netzwerkbeziehungen zwi- schen sozialen Bienen, sozialen Wespen und Pflanzen. Wir verglichen ein soziales Bienen- Pflanzen Netzwerk (BPN) mit einem sozialen Wespen-Pflanzen Netzwerk (WPN) unter der Fra- gestellung, ob verschiedene Arten von Mutualis- mus mit demselben Partner zu unterschiedlichen Netzwerkstrukturen führen. Hierzu wurden sozia- le Bienen und Wespen in einem Sammelgebiet mit Caatinga-Vegetation in Bahia bei ihren Blütenbe- suchen gefangen. Jedes zweiteilige Netzwerk wur- de dann in Form einer R-Nachbarschaftsmatrize be- schrieben. Wir beschrieben jedes Netzwerk in Hin- blick auf Schachtelung (nestedness NODF und N), Modularität (M) und Bedeutung einzelner Spezies (Ij). Beide Netzwerke erwiesen sich als geschachtelt}


(Abb. 1). Wir untersuchten weiterhin, inwieweit die beiden Netzwerkmaße (NODF und N) die Schachtelung in entsprechenden Nullmodellmatrizen (mit $\mathrm{n}=1000$ Zufallswiederholungen) quantifizierten, wobei Präsenzen zufallsverteilt den jeweils einzelnen Zellen der Matrix zugeordnet wurden. Die aus unseren Daten gebildeten Bienen-Pflanzen- und Wespen-Pflanzen-Matrizen wiesen allesamt eine tiefere Schachtelung auf als die Zufallsmatrizen. Das WPN bildete 116 der 546 möglichen Interaktionen $a b$ und zeigte eine Bindungsstärke von $\mathrm{C}=21,24$, während das BPN 72 der 456 möglichen Interaktionen aufwies, bei einer Konnektivität von $C=15,79$. Sieben der blütenbesuchenden Spezies bildeten den Kernbereich des WPN und sechs Arten erwiesen sich als von besonderer Bedeutung für die Struktur des BPN. Die Topologie des BPN war stark von der Gegenwart von Apis mellifera beeinflusst, einer eingeführten Art, die als Generalist Interaktionen mit 33 der 38 Pflanzenarten einging. Das Gesamtnetzwerk (OFPN) wurde aus 25 blütenbesuchenden Arten und 49 besuchten Pflanzen gebildet und hatte eine Konnektivität von 15,34. Insgesamt konnten wir 188 von 1225 möglichen Interaktionen finden, wobei neun Arten für $78,19 \%$ aller Verbindungen verantwortlich waren: Apis mellifera (33 Interaktionen), Polybia ignobilis (18), P. sericea (17), Polistes canadensis (17), P. paulista (15), Brachygastra lecheguana (13), Trigona spinipes (12), P. occidentalis (11) und Protonectarina sylveirae (11). Ein relativ hoher Anteil der Pflanzenarten $(63,3 \%, \mathrm{~N}=31)$ wurde sowohl von sozialen Bienen als auch sozialen Wespen besucht. Unsere Analysen der Beziehungsnetzwerke zeigten einen klaren Unterschied hinsichtlich der Bedeutung einzelner Pflanzenarten als Nahrungsquelle für die jeweiligen blütenbesuchenden Gruppen (Abb. 2). Die Modularität des Gesamtnetzwerks aus beiden Gruppen war relativ gering $(\mathrm{M}=0,07$, $P=0,004)$, was auf eine Überlappung zwischen Bienen und Wespen in den Blütenbesuchen zurückzuführen ist. Wir fanden zudem eine höhere Nischengruppierung innerhalb der Bienen als innerhalb der Wespen. Trotz der Unterschiede im fakultativen Mutualismus zwischen Bienen-Pflanzen (direkter Mutualismus - Bestäubung) und WespenPflanzen (indirekter Mutualismus - Verteidigung) wiesen die beiden Beziehungsnetzwerke ähnliche Topologien auf, mit geschachtelten Mustern und asymmetrischen, modularen Strukturen.

Blütenbesuchende Gilde / Nahrungsnetzwerk / Trophische Interaktionen / Semiaride Region

\section{REFERENCES}

Aguiar C.M.L. (2003) Utilização de recursos florais por abelhas (Hymenoptera, Apoidea) em uma área de caatinga (Itatim, Bahia, Brasil), Rev. Bras. Zool. 20, 457-467.

Aguiar C.M.L., Santos G.M. de M. (2007) Compartilhamento de recursos florais por vespas sociais (Hymenoptera: vespidae) e abelhas (Hymenoptera: Apoidea) em uma área de Caatinga, Neotrop. Entomol. 36, 836-842.

Aizen M.A, Morales C.L, Morales J.M. (2008) Invasive Mutualists Erode Native Pollination Webs, PLoS Biol. 6, e31, doi:10.1371/journal.pbio.0060031.

Almeida-Neto M., Guimaraes P., Guimaraes P.R., Loyola R.D., Urlich W. (2008) A consistent metric for nestedness analysis in ecological systems: reconciling concept and measurement, Oikos 117, 1227-1239.

Atmar W., Paterson B.D. (1993) The measure of order and disorder in the distribution of species in fragmented habitats, Oecologia 96, 373-382.

Bascompte J., Jordano P. (2006) The structure of plant-animal mutualistic networks, in: Pascual M., Dunne J. (Eds.), Ecological networks, Oxford University Press, Oxford, pp. 143-159.

Bascompte J., Jordano P. (2007) Plant-animal mutualistic networks: the architecture of biodiversity, Annu. Rev. Ecol. Evol. Syst. 38, 567-593.

Bascompte J., Jordano P., Melián C.J., Olesen J.M. (2003) The nested assembly of plant-animal mutualistic networks, Proc. Natl Acad. Sci. (USA) 100, 9383-9387.

Bascompte J., Jordano P., Olesen J.M. (2006) Asymmetric coevolutionary networks facilitate biodiversity maintenance, Science 312, 431-433.

Batagelj V., Mrvar A. (2003) Pajek - Analysis and visualization of large networks, in: Jünger M., Mutzel P. (Eds.), Graph Drawing Software, Springer, Berlin, pp. 77-103, http://vlado.fmf. uni-lj.si/pub/networks/pajek/.

Beggs J. (2001) The ecological consequences of social wasps (Vespula spp.) invading an ecosystem that has an abundant carbohydrate resource, Biol. Conserv. 99, 17-28.

Bezerra E.L.S., Machado I.C.S., Mello M.A.R. (2009) Pollination networks of oil-flowers: a tiny world within the smallest of all worlds, J. Anim. Ecol. 78, 1096-1101.

Biesmeijer J.C., Slaa E. J., Castro M.S., Viana B.F., Kleinert A. de M.P., Imperatriz-Fonseca V.L. (2005) Connectance of Brazilian social bee: food plant network is influenced by habitat, but not by latitude, altitude or network size, Biota Neotrop. 5, doi: 10.1590/S1676-060320050 00100010.

Dormann C.F., Fründ J., Blüthgen N., Gruber B. (2009). Indices, Graphs and Null Models: Analyzing Bipartite Ecological Networks, Open Ecol. J. 2, 7-24. 
França F., Melo E., Santos C.C. (1997) Flora de inselbergs da região de Milagres, Bahia, Brasil: I. Caracterização da vegetação e lista de espécies de dois inselbergs, Sitientibus 17, 163-184.

Gess F.W., Gess S. (1993) Effect of increasing land utilization species representation and diversity of aculeate wasps and bees in semi-arid areas of South Africa, in: La Salle J., Gauld I.D. (Eds.), Hymenoptera and Biodiversity, London, CAB, pp. 83-113.

Guimarães P.R., Guimarães P. (2006). Improving the analyses of nestedness for large sets of matrices, Environ. Modell. Softw. 21, 1512-1513.

Guimarães P.R., Rico-Gray V., Reis S.F. dos, Thompson J.N. (2006a) Asymmetries in specialization in ant-plant networks, Proc. R. Soc. London B 273, 2041-2047.

Guimarães P.R., Sazima C., Reis S.F. dos, Sazima I. (2006b) The nested structure of marine cleaning symbiosis: is it like flowers and bees? Biol. Lett. , doi:10.1098/rsbl.2006.0562.

Guimerà R., Amaral L.A.N. (2005) Cartography of complex networks: modules and universal roles, J. Stat. Mech.: Theory Exp., doi:10.1088/17425468/2005/02/P02001.

Heard T.A. (1999) The role of stingless bees in crop pollination, Annu. Rev. Entomol. 44, 183-206.

Heithaus E.R. (1979) Flower visitation records and resource overlap of bees and wasps in northest Costa Rica, Brenesia 16, 9-52.

Hermes M.G., Köhler A. (2006) The flower-visiting wasps (Hymenoptera, Vespidae, Polistinae) in two areas of Rio Grande do Sul State, southern Brazil, Rev. Bras. Entomol. 50, 268-274.

Hunt J.H., Brown P.A., Sago K.M., Kerker J.A. (1991) Vespid Wasps Eat Pollen (Hymenoptera: Vespidae), J. Kansas Entomol. Soc. 64, 127-130.

Jones G.D., Jones S.D. (2001) The uses of pollen and its implication for Entomology, Neotrop. Entomol. $30,341-350$.
Jordano P. (1987) Patterns of mutualistic interactions in pollination and seed dispersal: connectance, dependence asymetries, and coevolution, Am. Nat. 129, 657-677.

Jordano P., Bascompte J., Olesen J.M. (2003) Invariant properties in coevolutionary networks of plantanimal interactions, Ecol. Lett. 6, 69-81.

Memmott J., Waser N.M., Price M.V. (2004) Tolerance of pollination networks to species extinctions, Proc. R. Soc. London B 271, 2605-2611.

Murray K.G. (2000) The importance of different bird species as seed dispersers, in: Nadkarni N.M., Wheelwright N.T. (Eds.), Monteverde: ecology and conservation of a tropical cloud forest, Oxford University Press, New York, pp. 294-295.

Olesen J.M., Jordano P. (2002) Geographic patterns in plant-pollinator mutualistic networks, Ecology 83, 2416-2424.

Ollerton J., McCollin D., Fautin D.G., Allen G.R. (2007) Finding NEMO: Nestedness engendered by mutualistic organisation in anemone fish and their hosts, Proc. R. Soc. London B 274, 591-598.

Resende J.J., Santos G.M.de M., Bichara-Filho C.C., Gimenes M. (2001) Atividade diária de busca de recursos pela vespa social Polybia occidentalis occidentalis (Olivier, 1790) (Hymenoptera, Vespidae), Rev. Bras. Zoociências 3, 1-7.

Santos G.M.de M., Aguiar C.M.L., Gobbi N. (2006) Characterization of the social wasp guild (Hymenoptera: Vespidae) visiting flowers in the caatinga (Itatim, Bahia, Brazil), Sociobiology 47, 483-494.

Vázquez D.P., Aizen M.A. (2004) Asymmetric specialization: a pervasive feature of plant-pollinator interactions, Ecology 85, 1251-1257.

Wilms W., Wiechers B. (1997) Floral resource partitioning between native Melipona bees and the introduced Africanized honey bee in the Brazilian Atlantic rain forest, Apidologie 28, 339-355. 


\section{Appendix 1}

Plant species visited by social wasps and social bees in the caatinga of Itatim (Bahia State, Brasil).

\begin{tabular}{|c|c|c|}
\hline Plant species visited & Family & Plant species codes \\
\hline Acacia bahiensis Benth. & Mimosaceae & $\mathrm{AB}$ \\
\hline Alternanthera brasiliana (L.) Kuntze & Amaranthaceae & AT \\
\hline Anacardium occidentale $\mathrm{L}$. & Anacardiaceae & $\mathrm{AO}$ \\
\hline Boerhavia coccinia Mill. & Nyctaginaceae & $\mathrm{BC}$ \\
\hline Caesalpinia pyramidalis Tul. & Caesalpiniaceae & $\mathrm{CP}$ \\
\hline Capparis jacobinae Moric. & Capparaceae & $\mathrm{CJ}$ \\
\hline Capparis yco (Mart.) Eichl. & Capparaceae & $\mathrm{CY}$ \\
\hline Cardiospermum corindum $\mathrm{L}$. & Sapindaceae & $\mathrm{CC}$ \\
\hline Cereus peruvianus (L.) Mill. & Cactaceae & $\mathrm{CV}$ \\
\hline Chaetocalyx scandens (L.) Urban & Fabaceae & $\mathrm{CS}$ \\
\hline Chamaecrista belemii (I. \& B.) I. \& B. & Caesalpiniaceae & $\mathrm{CB}$ \\
\hline Chlorophora tinctoria (L.) Gaud. & Moraceae & $\mathrm{CT}$ \\
\hline Cordia aff. globosa (Jacq.) H.B. \& K. & Boraginaceae & CG \\
\hline Cordia latiloba I.M. Johnston & Boraginaceae & $\mathrm{CL}$ \\
\hline Croton echioides Baill. & Euphorbiaceae & $\mathrm{CE}$ \\
\hline Echinodorus subulatus Griseb & Alismataceae & ES \\
\hline Erythroxylon catingae Plowman & Erythroxylaceae & $\mathrm{EC}$ \\
\hline Eugenia rosea DC & Myrtaceae & ER \\
\hline Evolvulus glomeratus Nees \& Mart. & Convolvulaceae & EG \\
\hline Gomphrena holosericea Moq & Amaranthaceae & $\mathrm{GH}$ \\
\hline Herissantia crispa (L.) Briz. & Malvaceae & $\mathrm{HC}$ \\
\hline Herissantia tiubae (K. Sch.) Briz. & Malvaceae & HT \\
\hline Hydrocleis nymphaeoides Buch & Limnocharitaceae & $\mathrm{HN}$ \\
\hline Jacquemontia sp. & Convolvulaceae & JA \\
\hline Jatropha mollissima (Pohl) Baill. & Euphorbiaceae & $\mathrm{JM}$ \\
\hline Lippia pohliana Schau. & Verbenaceae & LP \\
\hline Melochia tomentosa $\mathrm{L}$. & Sterculiaceae & MT \\
\hline Mimosa arenosa(Willd.) Poir. & Mimosaceae & MA \\
\hline Mollugo verticillata $\mathrm{L}$. & Molluginaceae & MV \\
\hline Nymphoides indica (L.) Kuntze & Menyanthaceae & NI \\
\hline Opuntia palmadora Britton \& Rose & Cactaceae & $\mathrm{OP}$ \\
\hline Oxalis sp. & Oxalidaceae & OX \\
\hline Passiflora foetida $\mathrm{L}$. & Passifloraceae & $\mathrm{PF}$ \\
\hline Peltogyne pauciflora Benth & Caesalpiniaceae & PP \\
\hline Poeppigia procera Presl. & Caesalpiniaceae & $\mathrm{PO}$ \\
\hline Portulaca elatior Mart. & Portulacaceae & $\mathrm{PE}$ \\
\hline Portulaca marginata H.B. \& K. & Portulacaceae & PM \\
\hline Rhaphiodon echinus (Nees. \& Mart.) Schrad & Lamiaceae & RE \\
\hline Senna spectabilis (DC.) I. \& B. & Caesalpiniaceae & SS \\
\hline Sida galheirensis Ulbr & Malvaceae & SG \\
\hline Sida sp. & Malvaceae & SI \\
\hline Sidastrum paniculatum (L.) Fryxell & Malvaceae & SD \\
\hline Sideroxylon obtusifolium (R. \& S.) Penn. & Sapotaceae & SO \\
\hline Solanum gardnerii Sendtn & Solanaceae & SL \\
\hline Solanum paniculatum $\mathrm{L}$. & Solanaceae & SP \\
\hline Stigmaphyllon auriculatum (Cav.) A. Juss. & Malpighiaceae & SA \\
\hline Syagrus vagans (Bondar) A.D. Hawkes. & Arecaceae & SV \\
\hline Tabebuia heptaphylla (Vell.) Toledo & Bignoniaceae & TH \\
\hline Ziziphus cotinifolia Reiss. & Rhamnaceae & $\mathrm{ZC}$ \\
\hline
\end{tabular}

